\title{
해외긴급구호의 법적 기반 및 운영체계 연구: 일본, 호주, 스위스를 중심으로1)
}

\section{목차}

I. 서론

II. 일본의 해외 인도적 지원 및 긴급구호

III. 호주의 해외 인도적 지원 및 긴급구호

IV. 스위스의 해외 인도적 지원 및 긴급구호

V. 결론 및 제언

1) 본 논문은 한국국제협력단(KOICA)이 서울사이버대학교 산학협력단에 위탁하여 수행한 연구인 〈해외긴급구호의 법적 기반 및 운영체계 관련 주요 공여국 사례연구 (권구순, 이윤제, 홍문숙, 이경신, 하경화, 홍지영, 신선연, 신호진, 구소연)〉의 최종보고서의 주요 내용을 중심으로 연구책임자 권구순과 공동연구자 홍문숙이 재구성한 내용임을 밝힘. 연구보고서 전 체 원문은 KOICA 홈페이지와 도서관(http://www.koica.go.kr)를 통해서도 확인할 수 있음.

2) 02-944-5196 / jeremy-kwon@hotmail.com

3) 02-323-9110/moonshiely@redi.re.kr 


\section{초록(Abstract)}

한국은 정부차원에서 1990년대부터 전 지구적인 자연재난에 대한 긴급구호 활동을 개 시하였고 2004년 동남아지진해일 구호를 계기로 체계적인 해외재난구호의 필요성이 제기 되어 2007년「해외긴급구호에 관한 법 및 시행령」을 제정하였다. 이를 토대로 '대한민국 해외긴급구호대(Korea Disaster Relief Team, 이하 KDRT)'를 조직하여 해외재난구호활 동을 수행해왔다. 한편, 재난규모의 대형화와 피해당사국 정황의 복잡성과 같은 외부적 변수로 인해 $\mathrm{KDRT}$ 의 평시대비와 관련한 법과 운영측면의 개선이 지속적으로 요구되었 다. 이에 본 연구는 중장기적으로 $\mathrm{KDRT}$ 운영의 질적 개선을 위해 주요 선진공여국 중 권역별로 일본(아시아), 호주(영미), 스위스(유럽)를 선정하여 인도적 지원 및 긴급구호의 법제와 정책, 운영에 대한 문헌조사 및 유관기관 방문조사를 실시하였다.

연구결과, 다음과 같이 시사점 및 제언을 도출하였다.

법제는 3 국 공히 인도적 지원만을 규정하는 법을 제정하기보다 국제개발협력법에 인도 적 지원조항을 명시하거나 절차상 특별법을 제정한 점을 감안하여 현행법 개정 대신 중장 기적으로「국제개발협력기본법」에 인도적 지원 규범과 원칙에 부합하는 목적과 정의, 주 요원칙을 보다 구체적으로 명시하는 방안을 고려할 필요가 있다.

정책의 경우, 3 국은 구체적인 해외 인도적 지원 및 구호관련 정책과 전략의 수립 및 이 행체계 마련, 주기적인 점검과 개선을 실시하고 있었다. 따라서 우리 정부도 관련 정책과 전략의 방향성 검토를 통해 구체적인 이행전략과 주제 별 세부전략을 수립해야 한다. 또 한 초기 사전조사의 중요성을 감안, 사전조사단의 구성, 편성, 수행역할 등을 명문화하고 기 수립된 $\mathrm{KDRT}$ 의 평시운영체계가 제대로 이행될 수 있도록 운영협의회와 실무협의회를 통한 주기적인 모니터링 및 점검이 요구된다.

구호대 운영체계에 있어서는 3 국 모두 충분한 인적-물적 기반을 토대로 재난상황에 부 합하여 신속한 운영체계를 갖추고 있으므로 $\mathrm{KDRT}$ 도 주무부처인 외교부의 총괄조정 하에 부처 별 협조체계를 보다 원활히 구축하고 $\mathrm{KDRT}$ 사무국은 인력관리와 장비유지 예산확 보 및 구호대의 인력풀관리와 역량강화 시스템 마련이 필요하다. 물류는 외주관리, 기관 별 관리, 직영관리 중 재난대비 및 현지정황을 반영한 물류관리시스템 구축이 요구된다.

이와 더불어 재난취약국 대상 국가협력전략 수립 시 재난경감 반영, 민간섹터와의 다양 한 협력체계 구축을 제언하였다.

주제어: 인도적 지원, 긴급구호, 구호대, 재난경감 


\section{I. 서론}

한국 정부는 1990년대 초부터 대규모 해외재난에 대한 구호 활동에 참여해왔다. 특히 2004년 동남아지진해일 구호활동을 계기로 체계적인 해외재난구호의 필요성이 제기되어 2007년 「해외긴 급구호에 관한 법 및 시행령」을 제정하였다. 이어서 외교부는 2008년 OECD/DAC (개발협력위 원회, 이하 $\mathrm{DAC}$ )의 특별검토를 통해 제시된 5 개 권고사항 중 하나인 '인도주의, 중립성, 독립성 강화 및 수원국 수요에 기반 한 인도적 활동 강화, 다자원조채널 적극 활용에 대한 후속대책으로 2011 2015년까지의 무상 및 다자협력 계획을 포함한 '분야별 국제개발협력 기본계획'을 수립하 였다. 동 기본 계획에는 '분쟁·재해관련 인도적 지원 및 평화구축 노력 지원강화를 통해 세계 평 화와 번영에 기여가 6대 전략목표 중 제3목표로 포함된 바 있다. 이러한 법제 및 정책적 이니셔 티브에 근거하여 중앙 119 구조본부를 주축으로 하는 구조팀과 국립중앙의료원 의료인력 및 국제 보건의료재단의 인력풀로 구성된 의료팀, 한국국제협력단(Korea International Cooperation Agency, 이하 KOICA) 직원들이 참여하는 지원팀으로 '대한민국 해외긴급구호대(Korea Disaster Relief Team, 이하 KDRT)'를 조직하여 각종 대규모 해외재난에 파견해왔다.

한편 현행 법률은 인도적 지원의 4 대 기본원칙 중 인도주의만을 명시하고 재난 발생 직후의 긴 급구호에 대해서만 규정하여 재난 대응 사이클 - 예방 및 경감, 대응, 조기복구, 개발과의 연계 성과 수행요건 - 을 충분히 반영하지 못하고 있다. 또한 재난을 자연 재해로 제한한 나머지 국제 사회가 공동으로 대응할 필요성이 대두되는 '인적 재난, 만성적 재난, 무력충돌, 복합적 위기상황' 등에 개입하는데 한계가 있고 이러한 재난에 범위에 대응하는 광의의 인도적 지원 개념을 반영해 야 한다는 필요성이 제기되었다. 반면 $\mathrm{KDRT}$ 의 경우, 파견 대비를 위한 평시 관리가 각 팀별로 분산되어 있었으나 이를 유기적으로 통합 운영하는 방안이 추진 중에 있고 보다 체계적인 역량개 발을 위한 교육훈련 및 시뮬레이션 연습계획도 수립된 것은 중요한 진전이라고 할 수 있다. 이제 한국정부가 이러한 노력들을 통해 해외재난 발생 시 신속한 파견과 원활한 현지 구호 활동을 수 행할 수 있도록 연계해야 하는데 이를 위해서는 해외 인도적 지원과 긴급구호활동의 지식과 경험을 축적하고 있는 선진공여국의 우수사례를 조사함으로써 발전적 개선방안을 마련할 필요가 있다.

따라서 본 연구는 주요 선진공여국, 즉 아시아권에서 일본, 영미권에서 호주, 유럽권에서 스위 스를 조사대상국으로 추출하여 각국의 해외긴급구호 및 인도적 지원 관련 법·정책·전략과 더불 어 이를 근거로 구축한 유관 부처 및 기관별 조정체계와 실제 재난현장에 파견된 긴급구호대의 운영체계를 연구범위로 설정하였다. 연구는 정성적 연구방법을 채택하여 국내 및 조사대상국의 현황에 대한 기초 문헌 및 자료를 분석하였고 국내 및 조사대상국 유관부처 및 기관 담당자들을 대상으로 심층인터뷰를 실시하였다. 그리고 각국의 시사점을 토대로 현행 국내 법령과 정책의 개 선방향 및 운영체계에 대한 제언을 도출하였다. 


\section{II. 일본의 해외 인도적 지원 및 긴급구호}

\section{1. 법적 체계 및 정책}

일본은 한국과 가장 유사한 법적 체계를 가지고 있는데 자연재난의 경우 「국제 긴급원조대 (Japan Disaster Relief, 이하 JDR)파견에 관한 법률」과 무력충돌 시 구호를 위한「국제연합 평 화유지활동 등의 협력에 관한 법률」을 각각 제정하여 구호대파견에 관한 절차를 규율하고 있다. 또한 JICA 법(Law Concerning Japan International Cooperation Agency, 2014년 최종 개 정) 의 제 3 장 제 13 조는 JICA가 수행하는 인도적 지원 업무의 범위를 규정하고 있으며, 그 중에 서도 제1항 제 6 호에서는 "개발도상지역 등에서 발생하는 대규모 재난에 대해 국제긴급원조활동 $\ulcorner J D R$ 법」및 기타 국제긴급원조를 위한 기자재 및 그 외 물자를 비축 또는 공여한다”라고 명시 하고 있다. 이를 근거로 해외긴급구호에 대한 물품 지원의 의무를 포함하고 있다. 뿐만 아니라 제 2 항 제 1 호, 제 2 호는 "기구는 전 항의 업무 이외에 다음의 업무를 수행한다. 「JDR 법」에 기초한 국제긴급원조대의 파견, 이외 물자의 조달, 전송의 준비 등을 하는 것과 국제 긴급원조 활동에 필 요한 기자재 제공”을 언급하여 인력파견 이외에도 JICA가 JDR과 관련된 업무를 포괄적으로 수행 할 의무가 있음을 명시하고 있다.

[박스 1] 국제긴급원조대 파견에 관한 법률(2006년 개정)

- (국제긴급원조대 파견 법률의 목적) 해외 지역, 특히 개발 도상에 있는 해외 지역에 대해 대규모 재해가 발생하거나 또는 발생할 경우, 재해의 영향을 받거나 혹은 받을 우려가 있는 나라의 정부 또는 국제 기관(이하 '피해국 정부 등' 이라 함)의 요청에 따라, 국제 긴급 원조 활동을 행하는 인원을 구성원으로 하는 국제긴급원조대를 파견하기 위해 필요한 조치를 규정하고 특히, 국제 협력 추진에 기여하는 것을 목적으로 한다.

- (국제긴급원조대의 임무) 국제긴급원조대는 전조에서 규정하는 재해에 관한 다음의 제시된 활동(이하 '국제 긴급 원 조 활동’이라고 함)을 실시하는 것을 임무로 한다. 1. 구조 활동, 2. 의료 활동(방역 활동 포함), 3. 전2호에 언급된 것 외의 재해응급대책 및 재해복구를 위한 활동이 이에 속한다.

- (관계행정기관 협의) 외무대신은 피해국 정부로부터 국제긴급원조대 파견 요청이 있을 경우, 제1조의 목적을 달성하 기 위해 그 파견이 적절하다고 인정될 경우, 국제긴급원조대의 파견에 대한 협력을 요구하기 위해 피해국 정부 등으 로부터 해당 요청의 내용, 재해의 종류 등을 감안해, 별표에 명시한 행정 기관(다음조의 '관계행정기관’이라 함)의 장 또는 국가 공안 위원회와 협의를 실시한다.

- (외무대신의 독립 행정 법인 국제 협력 기구(JICA) 에 대한 명령) 외무대신은 제 1 조의 목적을 달성하기 위해 적당하 다고 인정되는 경우에는 독립 행정 법인 국제 협력 기구에 대해, 국제긴급원조활동을 전조의 규정에 의거해 행하는 중앙행정기관, 지방 공공 단체 또는 독립행정법인의 직원 그 외의 인력을 국제긴급원조대로 파견하도록 명할 수 있다.

출처：国際緊急了援助隊の派遣に関する法律 (2006) 
정책부문에 있어서는 인도적 지원을 '인간안보' 실현의 주요과정으로 인식하고 재난의 범위를 포괄적으로 규정하고 있으며 재난경감(Disaster Risk Reduction, 이하 DDR)의 중요성을 강조하 여 관련 세부전략을 수립 및 이행하고 있다. 특히, 일본은 개발협력의 도전과제와 범위가 더욱 다 양하고 복잡해지며 공적개발원조(ODA) 이외의 활동 및 재원에 대한 요구가 증대되고 있음을 고 려하여 2015년 2월, 기존 대강을 '개발협력 대강(Development Cooperation Charter)'으로 변 경하여 발표하였다. 본 정책문서에서 일본은 개발협력의 주된 철학으로서 평화, 안정, 번영에 대 한 기여를 일관되게 강조하고 있다. 특히, (1) 비군사적 목적과 협력을 통한 평화 유지, (2) 인간 안 보 증진, (3) 일본 경험과 전문성에 근간을 둔 대화와 협력을 통한 자립 지원을 기본 정책으로 언 급하고 있다(GOJ, 2015). 2015년 새롭게 제시된 일본 개발협력 정책 우선순위 역시 (1)보편적 가치의 공유 및 국제 평화 및 안정 증진을 위한 협력, (2) 개발도상국 및 일본의 경제 성장을 위한

제 I 장

제 II 장

섹

터

제 III 장 전략적 개발협력 제고, (3) 인간안보 증진, (4) 전략적 파트너십 수립이다. 또한 2015년 개발협력 전략 내에서도 국제 평화 및 안정과, 인간안보를 지속적으로 강조하고 있다(MOFA, 2015).

ODA백서(2013)는 “미래 투자로서의 개발협력(Development Cooperation as Investment in the Future)"에 방점을 두고 변화하는 ODA환경에 근거한 일본 ODA 방향 조정에 대한 내용을 담고 있다. 본 백서에서 일본 정부는 전 세계적으로 국제적 혹은 비국제적 무력충돌로 인해 발생 한 다수의 피해자들을 감안하여 '인간안보(human security)' 원칙에 근거한 ODA 필요성을 강조 하고 있다. 특히, 분쟁이나 내전 등으로 인한 상황에도 인간안보 개념에 근거한 $\mathrm{ODA}$ 를 강조한 다. 또한 본 백서에서는 재난경감과 긴급지원에 대한 협력의 중요성을 별도로 언급하고 있다. 재 난으로부터 인간의 생명을 보호할 수 있는 복원력을 갖춘 사회(resilient society)가 되도록 재난 경감을 주류화 하고, 모든 개발의 단계에서 고려되어야 함을 강조한다. 긴급지원에 있어서는 국제 사회 또는 피해당사국을 통해 JDR의 파견, 현물 및 현금을 지원하고 있음을 언급하고 있다 (GOJ, 2014). 물론 일본의 ODA정책이 인도적 지원 정책과 완전히 부합되는 것은 아니나, 유사 한 맥락을 보여주고 있다. 특히 일본 ODA정책에서 중요하게 언급하고 있는 '인간안보(Human Security)'의 개념은 인도적 지원 정책의 중요한 목적으로 포함되어 있음을 알 수 있다.

일본정부의 인도적 지원 정책 중 특히 대응(response)에 대한 구체적인 정책은 다섯 가지로 (1) 난민 및 국내실향민(Internally displaced persons, 이하 IDPs)에 대한 지원, (2) 긴급구호에서 조기 복구 및 개발로의 전환(smooth transition), (3) 자연재해의 적절하고 효과적인 지원, (4) 개 발원조 담당자의 안전, (5) 민·군 간 임무조정이다.

구체적으로 일본 정부는 난민 및 국내실향민에 대한 지원이 인간안보 뿐 아니라 해당 지역 내 평화와 안정성에 크게 기여함을 언급하며, 물자지원 뿐 아니라 자발적 재정착, 재통합을 지원하고 
있다. 난민 지원의 경우 대부분 세계식량계획(WFP), 유엔난민기구(UNHCR) 등 다자기구를 통한 현금지원 방식으로 진행하고 있는데 최근 UN에서도 가장 중요한 현안 중 하나로 대두됨에 따라 일본 정부 또한 관련한 지원을 증대할 계획이다. 둘째, 일본 정부는 긴급구호에서 조기 복구 및 재건으로의 전환(smooth transition)을 통한 재난 피해자들의 자립을 지원한다. 셋째, 일본은 자 연재해에 대한 경험을 보유하고 있는 국가로서 긴급원조대의 파견 뿐 아니라 재난경감분야에서도 선두적인 역할을 담당한다. 넷째, 개발원조 담당자의 안전에 있어 '인도적지원 활동 공간 (humanitarian space)'의 중요함을 언급하고 있다. 마지막으로 민 · 군 간 임무조정과 관련해서 대규모 자연재해 시, 군 보유 자산의 동원이 가능하나 원론적으로 민간 차원의 대안이 없을 경우 에만 군 보유 자산이 사용되도록 하고 있다. 특히 군 자산 동원은 국내 정치와 맞물려 난제(難題) 로 여겨짐에 따라, 외무성은 주로 '오슬로 가이드라인(Oslo Guideline)'을 참조하고, 아시아안보 포럼(ASEAN Regional Forum, ARF) 훈련도 참석하는 등의 방식으로 진행한다.

이러한 일본 인도적 지원의 5 대 정책 우선순위 결정은 당시의 인도적 지원 수행에 있어 가장 큰 장애가 무엇인지 판단하여 그에 대응하기 위한 전략을 우선순위에 놓은 것이다. 특히 전통적 으로 중요하게 생각하는 인도적 지원 개념(인간안보 등)과 국제적인 상황 및 당시 인도적 지원활 동과 관련하여 국제사회에서 이루어지는 담론, 타국의 대응 등을 종합적으로 고려하여 정책을 수 립하고 있다.

또한 일본은 $\mathrm{ODA}$ 를 통한 재난경감 이니셔티브(2005)와 재난경감 프로그램과 사업을 강조하 고 있다. 일본 외무성은 $\mathrm{ODA}$ 주요 분야 중 하나이자 인도적 지원 정책의 주요 우선순위로 재난 경감을 강조하고 있으며 관련 전략은 2005년부터 수립되어 시행중에 있다. 본 정책의 기본원칙은 재난경감과 관련하여 기본적으로 인간안보의 개념에서 자연 재해의 위협에 대응하는데 있다. 개 발도상국의 각 개인(특히 젠더 관점에서)을 중심으로 하되 전 지구적, 지역적, 국가적 차원에서의 고려가 필요함을 언급하고 있다.

일본 재난경감 전략의 주요 목적은 $\mathrm{ODA}$ 를 통한 개발도상국의 자립을 돕는 것으로서 기본 정책은 (1) 재난경감과 관련된 우선순위 제고(Raising the priority attached to disaster reduction), (2) 인간안보의 관점(Perspective of human security), (3) 젠더 관점(Gender perspective), (4) 소프트웨어 관련 지원의 중요성(Importance of assistance regarding software), (5) 지역적 으로 가용한 적정기술의 동원과 보급(Mobilization and dissemination of locally available and suitable technology), (6) 다양한 이해관계자와의 파트너십(Promoting partnerships with various stakeholders)으로 제시되어 있다. 이러한 재난경감의 주요 기본 정책과 원칙에 근거하 여 일본 정부는 재난경감 관련 협력 업무 실시에 있어 재난의 각 단계에 적합한 협력이 필요함을 강조하고 있다. 그 방안으로는 (1) 재난 예방을 개발 정책으로 통합하는 것, (2) 재난 직후 신속하 
고 적절한 지원을 하는 것, (3) 재건에서 지속가능발전으로 확대할 수 있도록 협력하는 것을 제시 한다.

각 방안별 구체적인 실행전략으로 첫째, 재난 예방을 개발 정책으로 통합하는 것과 관련하여 우선적으로 재난예방의 관점을 포함하는 제도구축이다. 이에 재난 예방을 위한 전문가 교육과 역 량강화가 필수적이며 지역사회의 재난경감에 대한 역량과 인식을 개선하는 것이 중요하다. 둘째, 재난 직후 신속하고 적정한 지원을 위해서는 즉각적이고 적절한 긴급구호 및 지원, 긴급대응을 위한 전문가 훈련 및 파견, 재난에 따른 식량 부족에 대응한 식량 지원, 재난 각 단계에 상응하는 일관적인 협력 전략이다. 세 번째 방안으로는 재건에서 지속가능발전으로 확대할 수 있도록 협력 하기 위해서 견고한 경제·사회 인프라와 건축물 확보를 위한 지원, 재난에 견고한 시스템과 기술 의 보급, 그리고 재건 및 개발에 필수적인 재정지원을 강조하고 있다.

제 I 장

제 II 장

터

제 III 장

\section{2. 국제긴급원조대 운영4)}

일본은 주무부처인 외무성이 해외긴급구호의 배타적 의사결정권을 토대로 부처 간 협력을 주도 하고 원조대 파견실무는 양자원조기관인 JICA 내 JDR 사무국(Secretariat)에서 총괄하고 있다. 따라서 인도적 지원 및 해외긴급구호에 대한 외무성의 결정사항에 따라 파견업무의 JDR 사무국 에서 전담한다. 사무국은 「JDR 법」에 근거하고, JICA 내부 규정에 따라 관련 업무를 수행하 고 있다. JDR 사무국의 주요 역할은 원조대의 파견, 물자 비축 및 공여를 중심으로 재난 정보 수 집, 원조대 요원 모집 및 등록, 훈련 및 연습, 장비 조달 및 관리, 국내 및 국제 조직 간의 연락 및 조정, 유엔재난평가조정단(UN Disaster Assessment and Coordination, 이하 UNDAC)과 국제도시탐색구조자문그룹(The International Search and Rescue Advisory Group, 이하 INSARAG)에 대한 기여 등이다. 사무국은 원조대의 인력 및 예산의 집행권한을 보유하고 있으 며, 장비수준 및 인력의 역량 강화를 위한 훈련 등 지원이 체계화 되어있다. JDR 사무국 내 $\mathrm{JICA}$ 정규직원은 소수이며 순환보직 되더라도 장기 계약직 직원을 고용하여 긴급구호 업무의 연 속성이 보장되도록 조치를 취하고 있다.

원조대는 구조팀과 의료팀으로 구성되는데 구조팀의 경우, 외무대신의 파견결정 이후, 24 시간 이내에 출국하는 것을 목적으로 하는데 향후 40 명 정도의 중소 구조팀과 장비로 출동하는 것을

4) 일본, 호주, 스위스의 국제구호대 운영(관리, 각팀별 현황, 인력관리, 장비관리, 장비 및 운송 절차, 단계별 대응절차 등) 에 관한 상세한 내용은 보고서의 2장 2절을 참고하기 바람. 전체 보고서는 아래 링크에서 확인 할 수 있음. http://lib.koica.go.kr/search/detail/CATTOT000000039626?mainLink=/search/tot\&briefLink=/search/tot/result?os=DE

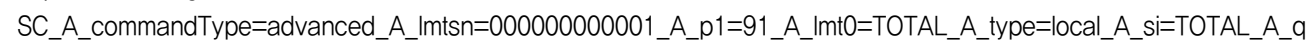

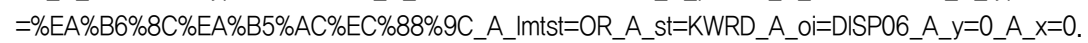


고려하는 등 구조조정(restructuring)을 현재 진행 중이다. 이는 네팔 지진 당시, 원조대 파견 및 물류 운송과정에서 우선순위 미 지정으로 인하여 물류 운송에 차질이 생겼고 네팔 현지 물류 시 스템이 열악하여 지게차 없이 수작업으로 짐을 옮겨야 하는 등의 난관을 경험한 후 구조팀의 편 성 인력 및 장비의 간소화 필요성 교훈을 반영하고자 함이다. 또한, 도쿄 경시청 소속 인력이 사 무국에 파견되어 인명구조에 대한 구체적인 기술 제공 및 구조팀을 구성하는 3개 기관(소방재난 관리청, 경찰청, 해상보안청)간의 합동 훈련 기획 등 사무국의 필요에 실질적인 역할을 수행하고 있다. 각 기관은 $\mathrm{JDR}$ 법」에 의거하여 인력의 파견 및 훈련을 소속기관의 임무로 간주한다. 인 력풀을 대상으로 각 기관은 예방접종, 관용여권 관리를 실시하며, 재난 발생 시 이들 인력풀이 국 제구호활동에 투입된다.

3 개 기관이 독립적으로 인력풀을 관리하고, 각 기관에 배정된 인원을 내부절차와 선발기준에 따라 선정한다. 파견 시에는 각 파견기관이 사전에 정한 순서에 따라 인력풀 내에서 파견 인력을 신속히 선발하여 JDR 사무국이 통지한 집결시간에 맞추어 나리타 공항으로 집결한다. 파견 이후 에는 원조대 대원이 복귀 후 개별적으로 건강 검진을 실시하면 비용을 지원하고, 외상 후 스트레 스 장애(post traumatic stress disorder, 이하 PTSD)에 대한 검사 및 상담 지원도 외주 업체를 통하여 실시한다. 그러나 각 기관 간의 보유 역량의 차이로 인력 파견 기관은 대원의 역량 강화 훈련을 자체 예산으로 실시하고 있으며 JDR 사무국은 연 2회 개최하는 합동 훈련을 통하여 편성 인력이 역할에 맞게 기능을 숙련하도록 한다.

의료팀은 주로 민간의료인력 중 소정의 연수를 이수한 인력풀에서 선발하여 운영하고 있다. 현 재 국제보건기구(WHO)에서 정한 제1종(Type1) 긴급의료팀(Emergency Medical Team, 이하 $\mathrm{EMT}$ ) 수준이나 궁극적인 개선 방향은 중형규모인 제2종(Type2) 수준으로 격상하는 것이다. 이 로써 입원환자의 수술까지 역량을 강화하고 더 많은 의료진을 훈련시켜 재난현장에서 긴급의료팀 조정셀(EMT Coordination Cell)에 인력파견을 목표로 하고 있다. 또한 전염병(예: 에볼라)에 대 응할 수 있는 특수 의료팀을 조직하고자 계획 중에 있다. 민간 의료진을 자원봉사자로 활용하는 의료팀의 경우, 인도적 지원에 대한 개인적인 신념이 투철한 의료인력들이 참여하고 재정적인 보 상은 별도로 없으나 체재비(숙박, 식비)를 JDR 사무국이 지불하는 방식이다. 사무국은 지난 10 년 간 EMT Type2를 준비해 왔으며, 국제사회의 EMT 담론에 적극적으로 참여하고 있다.

외교부 관계자가 원조대 대장을 역임하는데 평소 INSARAG 회의 및 훈련 등을 통해 국제구호 활동에 대한 학습을 토대로 재난현장에서 국제기구와의 협력 등 JDRT의 활동에 대한 의사결정자 로서 역할을 수행하도록 역량을 강화하고 있다. 현장과 본부 간의 의사소통은 3 개 기관과 JICA 소속 인력이 각각 부단장을 맡아 기관 간의 의견을 조율한 후 보고 채널은 외교부 소속 대장을 통하여 외교부로 일원화하도록 매뉴얼 상에 규정하고 있다. 
물류와 관련하여 JDR 사무국은 장비의 유지, 물류관리, 창고 운영 등의 물류 업무를 외주 계 약으로 업체에 위탁한다. 장비는 약품 및 구조 장비의 조달업체와 계약을 맺어 정기적으로 유지 및 관리될 수 있도록 하며, 일본해외원조협회(Japan Overseas Cooperation Agency, 이하 $\mathrm{JOCA}$ 가 물류의 제반관리를 맡고 일본통운의 창고에 물품을 바코드 시스템을 활용하여 체계적으 로 보관중이다. 재난 발생 시, 사무국으로부터 파견 준비 요청을 받으면 지참할 기본물품 리스트 를 전달받은 JOCA는 일본통운에 물품 불출을 지시하고, 공항까지 운송을 지시한다. 물품은 박스 단위로 포장되어 불출되며, 기적 가능한 사이즈에 맞게 파렛트로 포장한다. 원조대 장비의 구매는 전문가(구조-경찰청 파견 인력, 의료-JDR 의료팀 인력풀)의 조언(사양작업)을 토대로 JICA 조 달 규정에 따라 입찰로 구매하고 의료 기자재 및 의약품 관리는 인력풀 내의 약사가 창고를 방문 하여 약품을 관리한다. 약품 폐기와 관련하여 연 3회에 걸쳐 훈련을 실시하면서 물품의 우선순위 를 정하여 중요 필요물품을 먼저 항공 적재함으로 물류의 효율을 높이고 있다.

\section{III. 호주의 해외 인도적지원 및 긴급구호}

\section{1. 법적 체계 및 정책}

호주는 해외 인도적 지원 또는 긴급구호 관련하여 별도의 법령을 제정하지 않고 정책문서를 통 한 범정부 협의를 강조하는 체계를 구비하고 있다. 그러나 최근 호주 외교통상부는 해외 인도적 지원이 필요한 위기 상황에서 보다 효과적으로 민관전문가 파견이 가능하도록 별도의 법령이 필 요하다는 판단을 하여 관련 법률을 제정하였다. 즉, 해외 인도적 지원 및 긴급구호 상황에서 타 정부 부처, 유관기관 및 연구기관, 시민사회 기관 등에서 적절한 전문 인력을 채용하고 이들을 해 외로 파견하기 위해 법적 근거가 별도로 필요하다는 정책적 결정 하에 2011년「구호전문가 파견 에 관한 법률(Australia Civil Corps Act, 이하 ACC Act)」이 공표되었다.

$\mathrm{ACC}$ Act는 해외 인도적 지원 및 긴급구호 상황에 신속하게 대응하기 위해 유관전문가들이 한 시적으로 호주 정부를 대표하는 공무원신분으로 파견될 수 있도록 하는 특별법이라고 할 수 있 다. 따라서 ACC Act에 의거 파견되는 전문가들은 현 소속과 무관하게 전원 호주 연방정부의 공 무원의 신분으로 전환되며 이들의 활동은 호주정부 활동의 일환이 된다. 전문가 풀에는 연방정부, 주정부, 긴급구호 관련 유관기관 소속의 전 · 현직 공무원을 포함하여 각종 대학, 연구기관, 관련 전문기관 및 레드알(RedR)과 같은 민간단체에 소속된 전문가들이 대거 포함되어 있다. 
전술한 바와 같이 ACC Act를 제외하고는 유관법률이 부재하기 때문에 이러한 법령의 공백은 정책문서를 통해 범정부적 협의를 강조하는 것으로 보완하고 있다. 우선 범정부 차원에서 부처 간 기관 간 역할과 책무를 명확히 명시하고 이를 협의한 위기관리 프레임워크(Australian Government Crisis Management Framework, 이하 $\mathrm{CMF}$ ), 호주정부의 해외지원 계획 (Australian Government Overseas Assistance plan, 이하 AUSASSISTPLAN)을 중심으로 강 력한 인도적지원의 정책 드라이브를 펴고 있다. 그리고 위의 위기관리 프레임워크 하에 외교통상 부를 주축으로 부처 간 위기대응팀(Inter-departmental Emergency Task Force, 이하 $\mathrm{IDETF})$ 을 가동하고 있다. 또한 호주 외교통상부는 범정부 - 부처 - 원조기관 차원의 다양한 이행 전략(Implementation Plan)을 수립하고 있음을 확인할 수 있었다.

2015년에 처음으로 개괄적인 인도적 지원 전략을 세운 한국과 달리, 인도적지원의 역사가 긴 호주의 경우 위기관리 프레임워크 하위의 다양한 콘텐츠의 전략을 수립하고 이행하고 있는 것이 다. 인도적 지원 실행 전략(Humanitarian Action Policy), 재난경감 정책(DRR Policy: Investing in a Safer Future: A Disaster Risk Reduction Policy for the Australian aid program), 재난경감 프로그램에 있어 기후변화와 환경적 고려의 통합 활동 전략보고 (Integration in Practice: Integrating disaster risk reduction, climate change and environmental considerations in AusAID programs DRR) 등 인도적 지원 전 분야의 분야별 우선순위와 실제 프로그램의 주요 방향성을 설명하는 전략을 지속적으로 발표하고 있는 것은 주 목할 만하다. 한국 정부도 2015 년 인도적 지원 전략을 통해 분야별 세부 전 비교우위 분야를 아 동, 여성, 난민 등 취약계층에 대한 지원, 인도적 지원 교육 역량 강화, 구호-재난-개발 연계, 재난경감(Disaster risk reduction, 이하 DRR) 분야를 강조하고 있지만 각각의 주제별 프로그램 전략 수립은 추가로 필요한 사항이다.

표제 연구가 진행된 2015년을 기준으로 호주정부는 모든 국내외 재난에 대한 효과적인 대응을 위해서 오랜 시간동안의 협의를 거쳐 범정부적 조정(Whole-of-Government, 이하 WoG) 체계 를 구축하였고 이와 같은 협조체계를 강조하는 것이 특징을 나타내고 있다. 호주 연방정부와 관 련한 주요 부처 및 유관기관은 이와 같은 WoG 체계를 기반으로 '호주정부 위기관리 프레임워크' 를 준수하고 프레임워크의 프로토콜에 따라 위기 대응을 한다. 호주 정부는 프레임워크에서 합의 된 바를 바탕으로 관련부처 및 유관기관 간에 적절한 협력이 필요한 해외 재난 시에는 부처 간 위기대응팀이 위기관리 메커니즘 하에서 작동한다. 반면, 호주의 인도적 지원 관련 평가 및 보고 체계를 살펴보면 해외긴급구호 관련 모니터링 및 보고 체계 구축이 시급하다는 점도 제기되고 있다. 
[그림 1] 해외재난 대응 범정부 조정체계(WoG) 구도

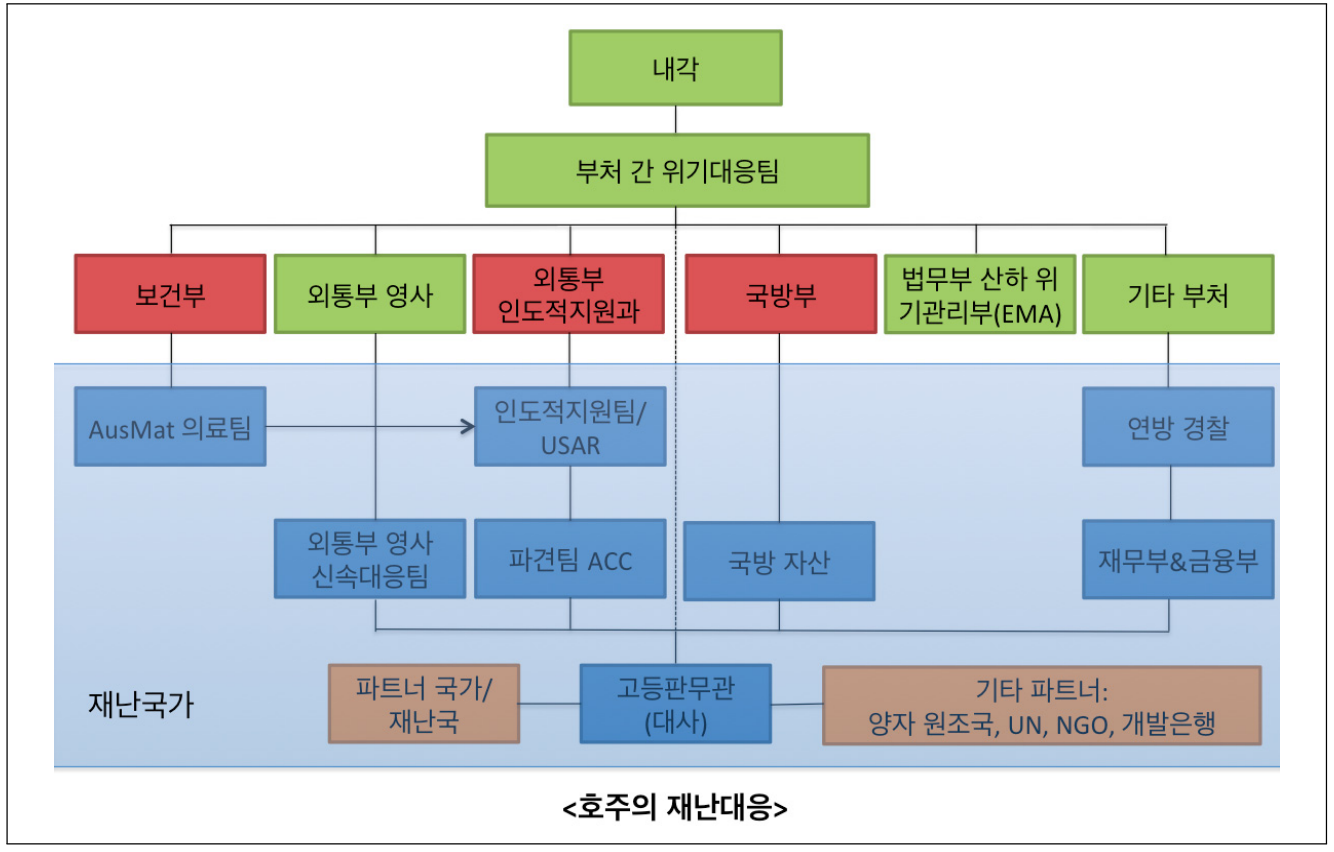

출처: CMF (2015)

\section{2. 긴급구호대 운영}

호주 연방정부는 위기의 성격과 규모, 재난이 호주에 미치는 영향력 등을 고려하여 재난대응을 이끌 주무 부처를 배정할 권한이 있으나 특별한 경우를 제외하고 해외재난 대응은 $\mathrm{CMF}$ 부속서 B. 6에 따라 외교통상부가 주무 부처로서 역할을 담당하게 된다. 해외재난 대응 시 외교통상부는 피해당사국의 재난지원 요청을 받아 지원을 위한 프로세스를 공식적으로 개시할 수 있다. 또한 재난지역의 정보 수집, 재정지원 등을 통해서 법무부 위기관리국(EMA), 보건부, 국방부 등 관련 부처가 해외 긴급구호대 파견 및 현물 지원을 할 수 있도록 총괄하고 지원하는 역할을 담당한다.

외교통상부의 역할과 책임에 있어서 2013년 토니 애벗 총리의 자유국민연립당(Coalition) 출범 후 외교와 $\mathrm{ODA}$ 의 통합성 제고를 목적으로 호주 국제개발청(AusAID)이 통합되면서 외교통상부 는 인도적 지원 및 해외 긴급구호 대응을 포함한 모든 대외정책을 담당하게 되었다. 그러나 외교 통상부는 재난에 대응하기 위한 통합된 사무국을 직접 운영하는 것이 아니기 때문에 관련 부처, 특히 재난대응을 위한 국내 프로세스에 조정을 담당하고 있는 법무부 위기관리국과 긴밀하게 협 력하는 것이 효과적인 해외 재난대응에 있어 핵심이라고 볼 수 있다. 외교통상부는 피해당사국과 
의 커뮤니케이션과 현지 대사관과 총영사관 및 외교통상부 소속의 위기대응팀(Crisis Response Team) 파견 등 다양한 경로를 통해 재난현장의 정보를 신속하게 수집하여 재난대응 전략을 세우 는 역할을 한다. 이러한 재난대응 전략을 바탕으로 재난의 성격과 규모에 따라 위기관리국과의 협력을 통해 지원 방식, 물류 수송 방식 등을 결정하고 각 부처 및 유관기관의 해외긴급구호대 파견에 필요한 재정 및 물류, 수송을 지원한다.

위기대응팀은 자국민 보호와 동시에 지원의 성격과 규모 등을 결정하기 위한 재난현장 정보 수 집이라는 두 가지 서로 다른 목적을 위해 파견한다. 동 팀은 외교통상부 소속으로 파견되지만 본 래 범정부 팀이기 때문에 물류, 조정 등 다른 역할을 각기 맡을 수 있도록 팀 구성원의 기술과 기 능이 분화되어 있다. 파견 시 전반적인 기능을 수행할 수 있도록 지속적으로 훈련되는 것이 특징 이다. 위기대응팀 규모는 풀(pool)에 등록된 사람이 약 100여 명으로 파견 시에는 등록된 사람 중 파견자를 선정하여 약 4 6명 정도의 소규모로 파견된다. 임무는 재난 현장에 파견되어 피해 규모를 산정하고 향후 긴급구호 및 인도적 지원 활동이 어떻게 진행되어야 할지 결정하기 위한 정보를 수집하는 것이다. 또한, 해외긴급구호대 파견 팀을 가지고 있는 관련 부처 및 유관 주정부 기관은 부처 및 기관 별로 임무 후 평가(after action review)를 의무적으로 진행하도록 규정되 어 있다. 관련 부처 및 기관에서 실시한 평가는 위기관리국을 거쳐 외교통상부에 전달되며 이들 은 개별 부처 및 기관의 평가와 파견에 대한 범정부 조정체계에 대한 평가를 통합하여 전반적인 임무 후 평가를 실행할 책임을 가지고 있다.

호주의 경우, 연방제 국가이기 때문에 해외긴급구호의 조정과 실행이 이원화 되어있어 긴급구 호대 운영 및 관리는 주로 주정부에서 담당하고 있다. 구조팀의 경우, 뉴사우스웨일즈와 퀸즈랜드 주정부의 소방국 대원들로 구성되고 의료팀은 보건부와 로얄다윈 병원 내 국립외상대응응급치료 센터(National Critical Care and Trauma Response Centre, 이하 NCCTRC)를 거점으로 구성 하나 재난피해지역과 재난상황을 전방위적으로 고려하여 의료팀을 파견한다. 이외에도 긴급구호 에 있어 호주군과 긴밀한 협력체계를 구축하였고 인도적 지원에 있어서도 주요민간단체와 긴밀히 협조하고 있다. 장비와 물류관리는 구조팀과 의료팀의 주축기관이 담당하고 있다.

뉴사우스웨일즈주 소방국의 탐색구조팀(AUS-2 USAR)은 주 정부의 소방 및 재난대응 역량 을 강화하고자 하는 노력이 곧 해외 재난 파견 시 호주 정부의 대표성을 갖는 활동기반 (fundamental)으로 귀결되므로 기초를 튼튼히 해야 함을 강조하고 있다. 이를 위해 구조팀은 INSARAG의 구호등급(IEC/IER) 등 동료검토 뿐만 아니라 타국의 소방 및 재난대응 역량에 대한 연구 및 의견 교환 등의 학습기회를 십분 활용하여 탐색구조팀에게 필요한 부분을 점진적으로 발 전시키는 데 적극 투자하고 있다. 예산의 규모, 시설 및 인력 등 주 정부 내에서 대응기관 (Combat Agency)로서의 입지를 확고히 하고 있으며, 특히 잉글번 훈련시설장은 실제 재난현장과 
같은 정교함을 지니며, 통신 및 구조장비의 보관 시설, 파견인력의 모집 동선 등으로 볼 때, 운영 의 효율성을 강조하기 위하여 공간을 최적으로 활용하고 있다. 구조팀 인력은 소방국 이외에도 외교통상부, 위기관리국 뿐만 아니라 주의 유관기관들(경찰, 재난대응, 공공인프라 등)로 다양하 게 편성되어 있으나, 상호 협약을 바탕으로 합의된 인식 하에(common understanding) 각자의 전문성을 최대한 발휘하되, 재난 상황을 전반적으로 고려하여 인력 및 장비를 배치한다.

뉴사우스웨일즈 의료팀(AusMAT)의 역할도 중요하다. 대규모 재난의 경우, NCCTRC를 거점으 로 AusMAT을 구성하나 재난피해 지역과의 거리를 중심으로 호주 정부의 정책적 우선순위에 부 합하는 재난 지역과 필요에 의거하여 의료팀을 파견한다. AusMAT 파견 결정의 근본 요인은 1) 재난지역으로부터의 공식적인 요청, 2) 지리적 근접성에 따른 외교통상부의 정무적 고려요소, 3) 주 정부의 보건 의료 역량 등이다. 그리고 다양한 역량을 보유한 의료팀을 전략적으로 파견하는 데, 예를 들어 EMT Type2의 야전병원(field hospital)을 운영할 수 있는 NCCTRC와 함께 필요 에 따라 뉴사우스웨일즈 등 주별 AusMAT의 Type 1도 활용하는 것이다. 주 정부 차원에서 AusMAT은 국내 및 해외 재난 파견을 담당할 뿐만 아니라 필요시 군과 함께 협진(Civil Military Medical Deployment)을 하는 등 재난현장에 따라 기능과 파견 형태를 다양화한다. 아울러 군수 송기를 활용하여 의료진의 인력 및 의료장비를 수송하는 등 원활한 이동이 가능하다.

구조팀의 경우, 헤비(Heavy)5) 등급에 부합하는 우수한 물류 역량은 자체 전담 인력(2명)의 창 의적이고 지속적인 표준화(standardization) 노력에 기인하며 뛰어난 대비상태-장비의 포장, 내 륙운송, 기적 등으로 인하여 ‘ 6 시간 이내’ 준비 완료가 가능하다. 또한 인력의 동원, 해제 계획을 비롯하여 현장지휘본부, AusMAT 의료캠프 설치 등에 대한 기본적인 구도(Layout Guidance)를 공유하고, 숙지해야 할 정보를 눈의 띄는 곳에 비치하여 누구든지 담당이 되면 할 수 있도록 한 다. 의료팀의 물류는 연방정부의 지원을 받는 NCCTRC가 의료진의 역량강화를 위한 훈련, 의약 품 및 장비의 보관, 조달 등 실질적인 AusMAT 파견의 중심 역할을 담당한다.

5) INSARAG에서 정한 도시탐색구조(USAR)팀의 역량을 구분하는 3개 등급(Light-Medium-Heavy) 중 상위등급으로 55명 이상의 관리, 탐색, 구조, 의료, 물류담당 대원을 보유하고 동시에 24 시간 동안 두 개의 재난지역에서 최대 10 일 간의 활동이 가능한 기술적 역량을 갖춰야 한다 (INSARAG, 2012). 참고로 한국의 KDRT는 2011년 헤비등급을 취득했다. 


\section{III. 스위스의 해외 인도적 지원 및 긴급구호}

\section{1. 법적 체계와 정책}

스위스는 전쟁을 포함한 무력충돌과 위기, 자연재해 등 재난에 영향을 받는 이재민들에 대한 스위스 시민들의 책임감과 연대를 반영하는 강한 인도적 지원 전통을 가진 국가로서 제 2 차 세계 대전 당시 시작된 인도적 지원의 오랜 경험과 중립국이라는 특성을 바탕으로 국제 인도적 지원의 발전을 선도하고 있는 국가이다. 또한 해외긴급재난에 대한 신속하고 효과적인 대응과 더불어 보 다 폭넓은 인도적 지원을 강조하여 재난의 예방과 대비에서 피해복구와 재건에 이르는 일련의 과 정을 총체적으로 접근하고 있으며 또한 이러한 인도적 지원 활동이 중장기적 차원의 개발로 연계 될 수 있도록 하고 있다.

국제개발과 인도적 지원에 오랜 전통을 가진 스위스는 연방 헌법에 전 세계의 평화와 번영을 스위스연방의 목표로 설정하였고 1976년 「국제개발협력과 인도적 지원법(Federal Act on Development Cooperation and International Humanitarian Assistance)」을 제정하여 국제 개발협력의 다양한 활동과 인도적 지원에 관련한 사항을 포괄적으로 규정하여 왔다. 특히 동 법 은 스위스에서의 인도적 지원이 국제개발협력의 다양한 활동 중 한 분야이기보다는 개발협력과 동등한 비중과 중요성을 가지고 있다는 것을 보여주고 있으며 주요 골자는 국제개발협력과 인도 적 지원의 목적, 원칙, 방식, 협력관계, 인도적 지원의 목표와 형태, 재정, 민간 활동 지원, 지방 자치단체와의 협력, 연방정부의 역할 등을 법적으로 규정하고 있으며 그 이행에 관한 주요 의무 를 스위스 연방평의회(Federal Council)에 위임하고 있다.

동 법의 제 1 장 제 1 조에서 제 4 조까지는 일반 규정(general provisions)을 다룬다. 제 2 조는 국 제개발협력 및 인도적 지원은 스위스와 다른 국제 공동체의 관계에서 연대성(solidarity)을 표현 하는 것이며 전 세계 다양한 구성원들과의 상호의존적인 상황에 대응하는 것임을 밝히고 있다. 또한 개발협력과 인도적 지원의 핵심적인 원칙으로써 협력대상국들의 권리와 이익, 상호 존중을 강조하고 해당 국가 국민들의 필요를 고려하여 이행되어야 할 것임을 명시한다. 제 3 조에 따르면 개발협력과 인도적 지원의 방식을 규정하는 데 개발협력과 인도적 지원은 일반적으로 양자나 다 자 형태로 이루어지나 필요한 경우 스위스의 독자적 지원도 가능하다. 제 4 조는 스위스의 개발과 인도적 지원 활동을 위해 도입할 수 있는 협력구조를 설명하는데 가능한 한 협력대상국들의 노력 혹은 동일한 목적을 가진 국내외 자원과 긴밀하게 공조할 것을 언급하고 있다.

동 법의 제 3 장 인도적 지원(Humanitarian Aid)에 속하는 제7조와 제8조에서는 범위, 목적, 
형태 등에 대해서 구체적으로 다루고 있는데 동 법 제7조에 따르면 인도적 지원이 요구되는 재난 의 범위를 자연재해 뿐 아니라 무력충돌을 포함한 재난으로 인해 인간의 생명이 위협당할 때로 규정하고 있다. 그리고 인도적 지원이 재난의 예방, 구조 등 긴급 대응을 통해 생명을 구하고 고 통을 경감하는 것을 목적으로 함을 재확인한다. 제8조에서는 인도적 지원의 일반적인 형태를 첫 째, 물자지원, 둘째, 현금지원, 셋째, 전문가 및 구조대 파견으로 세분화하는 동시에 마지막으로 제 7 조의 목표를 달성하기 위한 기타 모든 형태를 포괄적으로 규정하며 필요시 여러 가지 형태의 지원을 동시에 결합하여 사용할 수 있음을 명시한다. 이어서 동 법 제9조 제 1 항은 개발협력 및 국제적인 인도적 지원에 대한 예산이 개방형 프로그램 방식으로 다년(several years)에 걸쳐 배 분된다고 규정함으로써 스위스 연방정부가 4개년도 기준으로 관련 정책을 수립하고 이행할 수 있 는 법적 근거를 제공한다. 동 법의 제 3 항은 연방평의회가 신규 프로그램을 위한 예산 배분을 의 회에 제안할 때, 연방평의회에게 효율적인 자원배분을 할 의무를 부과한다. 제 11 조 제 1 항은 연방 평의회가 본 법에 명시된 목적을 준수하는 민간단체의 활동을 지원할 수 있다고 명시함으로써 스 위스 비정부기구(NGOs)나 재난지역의 현지 NGOs들이 스위스개발협력청(Swiss Agency for Development and Cooperation, 이하 SDC)의 파트너로서 예산을 지원 받아 활동할 수 있는 법 적 근거를 제공한다.

민간과의 협력에 이어 동 법 제 12 조와 제 13 조는 각각 연방정부, 주정부, 지방자치단체의 역할 과 협력을 규정한다. 먼저 제 13 조는 연방평의회에 국제개발협력 및 인도적 지원과 관련해 연방정 부 내 조정의무를 위임하며 이를 위해 부처 간 위원회를 설립할 수 있다고 명시한다. 또한, 제 12 조는 스위스 연방평의회가 개발협력과 인도적 지원을 이행하는 주정부(Cantons)와 지방자치단 체(Communes), 공공기관(public institution)과 협력하거나 그들의 활동을 지원할 수 있다고 명 시한다. 동 법령을 근거로 주정부와 지방자치단체 등은 연방정부를 거치지 않고 직접 국제개발협 력 및 인도적 지원 활동을 자체적으로 펼칠 수 있으며 이에 대한 예산을 연방정부가 지원할 수 있다.

따라서 스위스의 경우 국제개발협력과 인도적 지원을 같은 법률에서 다룸으로써 긴급재난구호 를 비롯한 인도적 지원 활동이 국제개발협력 활동이 연계되어 이행될 수 있도록 법적 체계를 갖 추고 있다.

스위스의 인도적 지원정책에 있어 궁극적인 목표를 첫째, 인명 구조와 고통의 경감, 둘째, 기 초적 사회 서비스의 회복과 재난 피해지역의 역량 강화로 선정하고 이를 달성하기 위하여 긴급재 난지원, 재건과 회복, 재난위기 경감 등의 정책을 수립하여 추진하고 있다(SHA, 2013). 특히 인 명 구조와 고통의 경감 목적을 위해 첫째, 재난경감을 포함한 예방과 준비, 둘째, 재난 시 인명 구조와 이재민들의 기초적 필요 충족, 셋째, 재건과 복구를 그 세부 목적으로 둔다. 또한 정책문 
서는 이재민의 고통경감과 회복력을 기준으로 두고 우선전략 분야를 선정하고 있다. 재난 발생 시 긴급대응보다 재난 예방의 중요성에 주목하면서 인도적 지원활동과 개발협력 활동이 연계되는 통합적인 접근이 중시되었고 전문가 파견 등이 강조되고 있다.

2004년부터 2013년까지 10년 간 스위스의 인도적 지원 예산 규모는 전 세계 13위 규모이며 2009년 이후 인도적 지원 예산 규모는 지속적으로 증대되어 2013년 당시에는 총 ODA 예산의 약 $17.8 \%$ 를 차지했는데 이는 전년 대비 $16 \%$ 증가한 규모이다(GHD, 2003). 모든 인도적 활동에 서 인도주의(Humanity), 중립성(neutrality), 공평성(impartiality), 독립성(independence) 등 4 개의 핵심 인도주의 원칙과 모든 정치적 고려로부터의 자유 등의 원칙들을 고수하고 있다.

[표 1] 스위스의 주요 원조 정책과 인도적 지원 전략

\begin{tabular}{|c|c|c|}
\hline 년도 & 주요 원조 정책 & 주요 인도적 지원 정책 및 전략 \\
\hline 2002 & - & $\begin{array}{l}\text { (전략 분야) Switzerland position on the Post } 2015 \text { framework for } \\
\text { disaster risk reduction }\end{array}$ \\
\hline 2005 & $\begin{array}{l}\text { Humanitarian Aid of the Swiss } \\
\text { Confederation Strategy } 2010\end{array}$ & \\
\hline 2008 & - & (기관 전략) SDC Guidelines on disaster risk reduction \\
\hline 2009 & - & (기관 전략) SDC Cash for herders Asia Brief \\
\hline 2010 & - & (전략분야) Reconstruction and rehabilitation concept \\
\hline \multirow[t]{2}{*}{2011} & $\begin{array}{l}\text { Swiss Foreign Policy Strategy } \\
\text { 2012-2015 }\end{array}$ & (기관 전략) SDC Humanitarian Aid: Emergency Relief \\
\hline & - & (전략분야) Effectiveness Reporter-DRR in International Cooperation \\
\hline \multirow{3}{*}{2012} & - & (전략분야) Climate, Environment, and DRR Integration Guidance \\
\hline & \multirow{2}{*}{$\begin{array}{l}\text { Message on International } \\
\text { Cooperation 2013-2016 }\end{array}$} & (기관 정책문서) SDC Multilateral Humanitarian aid concept \\
\hline & & $\begin{array}{l}\text { (기관 정책문서) SDC Portrait: The SDC- reliable, sustainable, } \\
\text { innovative }\end{array}$ \\
\hline \multirow[t]{2}{*}{2013} & $\begin{array}{l}\text { OECD DAC Peer Review } \\
\text { Switzerland } 2013\end{array}$ & \\
\hline & Swiss Humanitarian Aid & (전략분야) Swiss Working Paper on DRR in the post 2015 agenda \\
\hline 2014 & - & (기관 평가) SDC-Evaluation completed lists 2013 \\
\hline
\end{tabular}

출처: 문헌조사 및 관계기관 방문조사에 근거하여 저자가 재구성 


\section{2. 긴급구호대 운영}

인도적 지원 정책 이행과 관련하여 $\mathrm{SDC}$ 는 범정부적 차원에서 강력한 지지를 받고 있다. 구체 적으로 $\mathrm{SDC}$ 는 특히, 해외긴급구호와 관련하여 연방평의회로부터 전권을 위임받아 구호대 파견 등을 포함하여 긴급구호활동과 관련한 전반적인 결정을 독자적으로 할 수 있고 또 결정사항을 이 행할 수 있다. 구호대는 구조팀과 신속대응팀(Rapid Response Team)으로 구분되는데 구조팀은 8 개의 민관군 기관의 전문 인력들이 참여하는 통합조직으로 구성되어 있고 구조팀의 활동이 용이 하지 않을 경우, 현지 재난상황에 따라 모자보건 의료팀을 포함한 신속대응팀을 유연하게 운용함 으로써 효율성을 제고하고 있다. 장비 및 물류관리는 $\mathrm{SDC}$ 의 인도지원국(Humanitarian Aid and Swiss Humanitarian Aid Unit, HA/SHA)에서 통합 관리하는 형태를 취하고 있다.

[그림 2] 인도적 지원 이행 체계 구조도

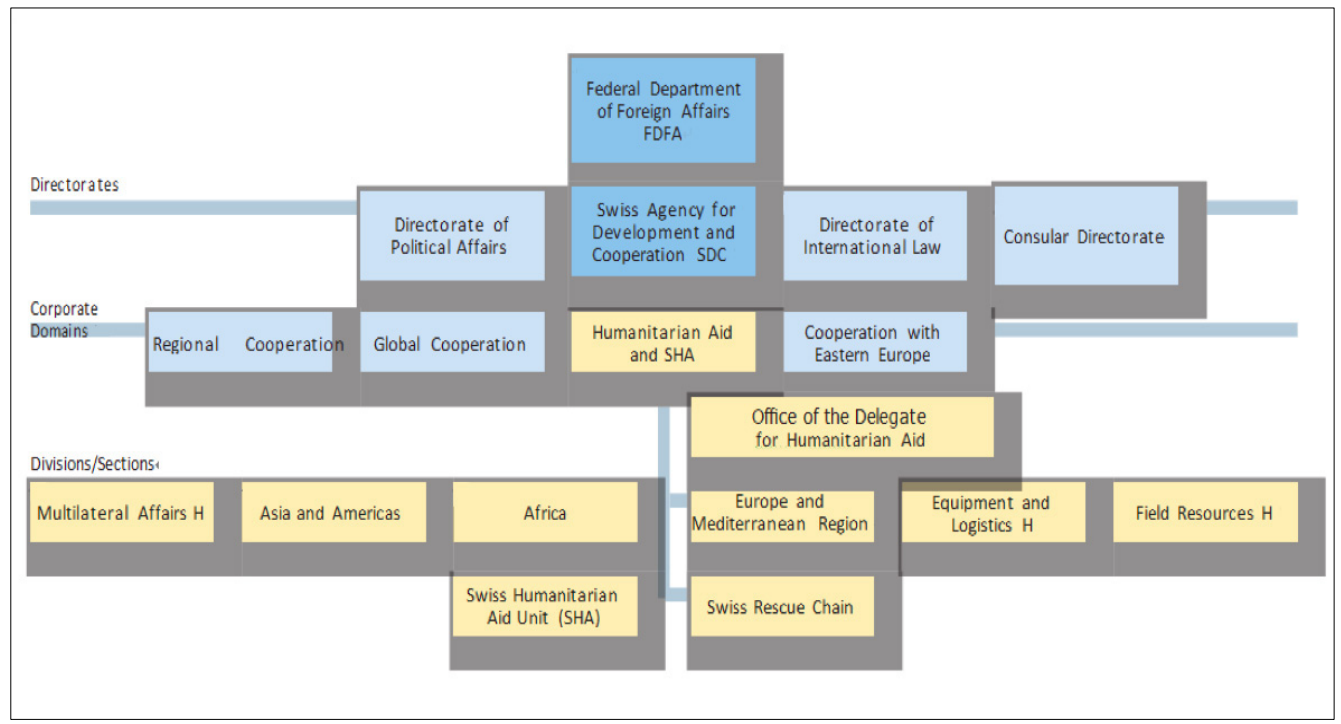

출처: SDC (2012) The SDC Multilateral Humanitarian Aid Concept

주목할 것은 구호대의 파견 및 운영에 관한 전권을 $\mathrm{SDC}$ 의 부서장인 인도적 지원국장이 행사하 면서 긴급구호의 신속성을 담보하고 있다. 이로써 현장의 다양한 수요와 변화에 긴밀한 대응이 가능하며 대응의 효과성을 증진하는 데에 기여하고 있다. 구호대의 형태도 현지 재난 상황에 부 합하도록 다양한 형태와 모듈을 유지하여 유연한 대응이 가능하다. 
[그림 3] HA/SHA 조직도

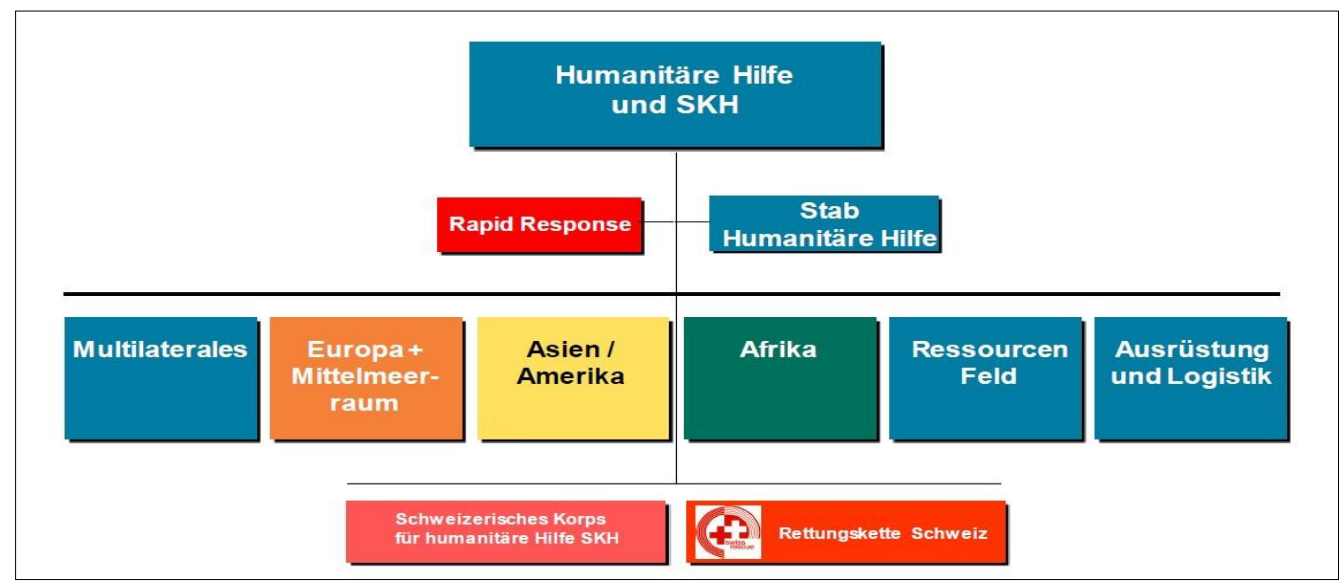

출처: SDC (2015) Rapid Response

긴급대응 방식 중 구호대 파견이 항상 우선시 되지 않으며 비용의 효과성을 고려하여 전략적인 영역에서의 선택과 집중이 이루어진다. 지리적인 이유로 구조팀 위주의 구호대 활동이 효과를 담 보할 수 없다고 판단되면 대신 다양한 형태의 RRT를 파견하여 구호활동을 전개하거나 UN 등 협 력기관에 전문가를 파견하여 대형 구호대 없이도 여러 개입방법을 선택함으로써 스위스의 인도적 지원 활동을 알리는 데에 기여하고 있다. 특히 RRT의 일환으로 모자보건 의료팀(Mother \& Child)을 파견할 경우에도 피해당사국의 산부인과/소아과 수요가 있을 때에만 파견을 결정하여 지원의 중복을 방지한다. 또한 스위스 정부는 스위스 구조팀 및 RRT의 활동을 위하여 사전에 체 계적 교육을 제공하여 유사시에 대비할 수 있는 역량강화에 주력하고 있다. 또한 피해당사국의 재난대응역량강화를 위하여 스위스 구호대의 전문적 기술을 이전하기 위한 노력을 지속하므로 재 난대응의 현지화에 기여하고 있다.

주요물자와 비품의 물류관리의 경우 SDC 인도지원국에서 직영체제로 운영하고 있는데 신속하 고 효과적 대응을 위한 선제 조건 중 하나로 물류 분야에 충분한 인력과 자원을 확보하고 물류 전담 조직을 구비한 것이 특징이다. 소모품은 구호대 파견결정 즉시, 규모에 따라 $\mathrm{HA} / \mathrm{SHA}$ 물류 팀에서 10 일간의 독자적 생활이 가능한 수준의 물자를 사전에 계약이 체결된 업체에 주문서를 제 출하면 해당업체는 업체의 물류창고에서 주문 완료된 물품을 준비하여 취리히 공항으로 7시간이 내에 운송할 수 있도록 조치를 취한다. 이처럼 자체물류관리와 더불어 다양한 유관 기관과 사전 협약 및 네트워크 구축을 통하여 원활한 인력 및 장비, 구호물류수송이 가능하도록 구축되어 있다. 


\section{V. 결론 및 제언}

\section{1. 법제}

제 I 장

제 II 장

일본, 호주, 스위스의 해외긴급구호 및 인도적 지원 관련 법제를 조사한 결과 각 국별로 추구 하는 인도적 지원 및 해외긴급구호의 목적과 정부조직체계가 서로 상이함에 따라, 법적 기반도 이러한 차이를 반영하고 있지만 대체적으로 다음과 같은 함의를 도출할 수 있었다.

첫째, 3 국의 공통적 특징은 해외 인도적 지원 활동만을 별도로 법제화하지 않았다는 것이다. 이는 국제인도법과 인권법, 난민법과 같은 관련 국제법이 이미 제정되어 여러 선진 공여국들이 이를 비준한 바 있고 대규모 재난피해자의 고통경감이라는 인류애에 근거한 인도적 지원은 전술 한 국제법에 근거하거나 인도적 지원정책을 수립함으로써 수행이 가능하다는 인식을 하고 있기 때문이라고 볼 수 있다.

둘째, 조사대상국의 법제화 유형은 기존 국제개발관련 법령에 인도적 지원을 동급 혹은 일부로 반영하거나 인도적 지원과 구호활동을 원활하게 집행할 수 있도록 특별법을 제정하는 것으로 조 사되었다. 보다 구체적으로 스위스의 경우, 국제개발협력과 인도적 지원의 중요성을 동일하게 간 주하여 국제개발 관련 법령에 해외 인도적 지원을 포함하여 법제화한 대표적인 사례이다. 또한 영국도 「국제개발법(International Development Act, 2002년 개정)」의 제1부 제3조에 인도 적 지원규정을 포함하고 있다. 한편 일본의 경우, 「JDR 법」을 제정하여 긴급구호활동에 있어 관 계부처 간 협조절차 등을 규정하였고 호주는 해외 인도적 지원뿐만 아니라, 재난경감과 복구활동 을 수행하는 민관 전문가들의 법적 지위와 제반 활동을 규정하는 법률을 제정한 바 있다.

셋째, 위와 같은 법제와 연계하여 각국들은 인도적 지원과 긴급구호활동을 보다 구체적으로 이 행할 수 있도록 국제개발 혹은 인도적 지원정책을 수립하고 있다. 특히 조사대상국 대부분은 주 무부처(외교부)가 수립한 인도적 지원정책에 근거하여 제반 활동을 수행하고 변화하는 국제 인도 적 지원환경과 맥락을 고려하고 자국의 외교정책을 반영하기 위해 주기적으로 수정 및 개선시키 는 양태를 보여주고 있다.

이에 현행「해외긴급구호에 관한 법 및 시행령」의 개정보다는 중장기적으로 스위스나 영국과 같이 국제개발협력을 포괄적으로 규율하는 「국제개발협력기본법」에 인도적 지원 규범과 원칙에 부합하는 목적과 정의, 주요원칙을 명시하는 개정을 고려할 필요가 있다. 


\section{2. 정책과 전략}

정책과 전략적인 측면에서는 일본, 호주, 스위스의 해외긴급구호 및 인도적 지원 관련 정책은 각 국별로 가지고 있는 정책과 인도적 지원을 주도하는 주무 부처 및 기관의 역할에 따라 다르게 발전되어 왔음을 확인하여 다음과 같은 함의를 도출할 수 있었다.

첫째, 국가별로 범정부 차원의 해외 인도적 지원 정책방향, 전략, 비전을 수립하고 주기적으로 혹은 필요시 재검점하고 있다. 국내외 위기관리 전략을 아우르는 호주의 범정부적 위기관리 프레 임워크처럼 향후 우리 정부도 외교적으로 영향력 있고 효율적인 정책성과를 기대하기 위해서는 좀 더 명확한 정책의 방향과 실천 전략을 범정부 적으로 협의해야 할 것이다.

둘째, 이와 같은 맥락에서 본 연구의 조사대상국은 다양한 인도적 지원의 이행전략의 수립하고 주제별 세부 전략 프로그램을 보유하고 있다. 정책적 비전과 목적을 달성하기 위해서 호주 및 스 위스에서 볼 수 있는 명확한 이행전략(Implementation Strategy)의 수립이 요구되며, 필요한 주 무 부처와 이행 기관 차원에서 예산, 정책 대상 및 기준, 정책달성 목표, 달성 기간, 달성 지표, 관련 법령 - 체계 정비 및 인적 역량강화 등을 포함한 구체적인 이행전략을 수립하는 것도 필요하 다. 특히, 호주의 강력한 정책과 협력 체계의 메카니즘 및 스위스의 다양한 인도적 지원 분야 프 로그램 전략을 벤치마킹 할 수 있으며, 중장기적으로 정책 우선순위 대상에 따라 여성, 난민, 교 육, 재난경감, 인도적 지원과 개발의 연계 등 각 분야에서의 정책 목표와 이행전략, 성과 평가 기 준 등을 포함한 분야별 세부 전략이 수립된다면 보다 효과적인 인도적 지원과 긴급구호활동을 수 행할 수 있을 것으로 기대된다.

셋째, 긴급구호대의 평시 운영과 사전조사에 대한 내용이 주요 전략에 부각 될 필요가 있다. 우선, 평시운영과 관련 아국처럼 다수의 부처 및 유관 기관이 참여하는 해외긴급구호 운영체계 하에서 재난 발생 시 신속하고 효율적인 대응을 가능하게하기 위해서는 재난발생 대비, 파견대상 자 훈련, 물류 준비, 현지정보 취합과 공유 등을 포함하는 평시 운영체계를 강화할 필요가 있다. 이를 위해 $\mathrm{KDRT}$ 운영협의회 및 실무협의회가 조직된 것은 매우 고무적이며 두 협의체의 정례적 인 회의와 논의를 통해 부처와 기관의 역할이 보다 구체화되고 사무국을 담당하는 KOICA 뿐만 아니라 참여기관 대원들의 전문성을 증대하기 위한 환경을 좀 더 적극적으로 구축해야 할 것이 다. 사전조사는 스위스와 일본의 경우 외교부 및 긴급구호대의 사전조사에 대한 권한과 역할규정 이 주목할 만하다. 왜냐하면 최근 인도적 위기의 성격과 지역적 정황에 따라 필요를 정확하게 파 악하기 위한 사전조사 필요성이 증대되고 있기 때문이다. 따라서 한국정부는 재난대응의 성과를 증진시키는 핵심적인 요소인 신속한 사전조사를 위해 민관합동해외긴급구호협의회가 주무 부처 및 $\mathrm{KDRT}$ 사무국에 사전조사의 명확한 권한과 책임의 정의를 관련 정책과 전략에 강조할 할 필 
요가 있다.

넷째, 해외 인도적지원의 정책 및 전략을 세부적으로 조사한 결과, 인도적 지원 분야 평가, 모 니터링 및 보고 체계 구축이 향후 가장 중요한 과제로 남을 것이다. 우리나라 인도적지원은 중장 기 국제개발협력 사업 대비 인도적 지원 거버넌스 차원의 평가 체계, 기관 차원, 전략차원, 사업 차원의 평가와 모니터링 체계가 미비한 상태이다. 해외긴급구호대책 수립 및 운영을 위한 권한과 국회에 대한 보고의 책임이 외교부장관에게 있다고 명시하고 있으나 신속하고 효과적인 긴급구호 대 활동을 가능하게 하는 평시대비, 평시 운영에 관한 내용과 유관부처의 관련 사항 이행을 주무 부처가 모니터링하고 평가할 수 있도록 해야 할 필요가 있다. 특히, 국제사회에서 통용되는 인도 주의 원칙인 $\mathrm{GHD}$ 의 목표와 지표를 중심으로 인도적 지원의 효과성 제고 방안을 수립하여 전략 차원과 사업차원의 평가와 보고 체계를 구축해야 하며 이를 위한 해외 동향과 평가 결과에 대한

제 I 장

제 II 장 후속조치가 향후 중요한 인도적지원의 정책 과제로 부상될 것이다.

\section{3. 긴급구호대 운영체계}

$\mathrm{KDRT}$ 의 운영측면에서는 한국의 인도적 지원과 해외긴급구호가 국제개발협력의 진화 및 발전 과 맥을 같이하고 있지만, 대체로 재난대응이 중심이 되다 보니 $\mathrm{KDRT}$ 를 포함한 인도적 지원 운 영체계의 양적·질적 개선이 필요하다. 이러한 개선과제는 2008년 $\mathrm{OECD/DAC}$ 의 특별검토나 2012년 실시된 동료검토에서도 권고된 바 있는데 한국의 경우 전략적으로 선정된 인도적 지원의 형태와 유형에 대한 사전 준비와 대응을 하는 운영체계를 갖기 위해서는 상위의 정책이 좀 더 강 화될 필요가 있다는 시사점을 얻을 수 있었다. 그 한 예로 재난취약국을 대상으로 국가협력전략 수립 시 재난경감을 포함시키는 것이다. 더불어 스위스와 같이 자국 구호대 파견에 대한 실익을 전략적으로 판단하며 재난취약국이나 그 주변국 중 동원가능한 정부구호대가 있을 경우, 이들에 대한 장기적인 역량강화 지원을 통해 $\mathrm{KDRT}$ 파견이 현실상 용이하지 않을 것에 대비하여 현지차 원의 대응역량을 증진시키는 것도 좋은 대안이 될 수 있다.

다양한 민간섹터와의 협력체계 구성 또한 현재 정책과 운영체계 부분에서 심도 있게 고려되어 야 할 부분이다. 스위스는 정부구호대 자체에 민간단체가 적극적으로 참여하고 있어 협력체계에 관해 많은 시사점을 준다. 호주정부도 현재 정부구호대와 민간단체 간 협력체계가 없지만, 의료팀 의 경우 민간단체가 기초보건유닛(Primary Health Unit)을 운영할 수 있는 인력과 장비 등 역량 을 갖출 경우, 협진이나 환자이송과 같은 협업을 전향적으로 고려하고 있다.

무엇보다도 3 국의 조사를 통해 얻은 중요한 시사점은 해외긴급구호대책을 통해 마련된 관리체 
계를 조직화, 상설화하는 동시에 인력과 예산을 확보하여 평시관리에 만전을 기하고 있다는 점이 다. 우선, 구호대 전문 인력풀을 늘리고 확보된 인력의 역량을 체계적으로 확충하며 각종 물자와 장비도 구호대의 역량에 부합하도록 구비하고 있다. 우리 외교부와 KOICA도 해외 타 부처와 해 외긴급구호 전담 기관과 같이 각각 주무부처와 실행기관으로서 UNDAC 구성원 수준의 현지조사 및 대응역량을 개발하여 재난발생 시 $\mathrm{KDRT}$ 를 주도적으로 이끌 수 있도록 할 수 있는 역량이 구 비되어야 할 것이다.

$\mathrm{KDRT}$ 는 2010년의 조직된 짧은 역사 속에서도 피해당사국에 대한 현금과 물자공여와 더불어 한국정부의 인도적 지원의 한 축으로써 생명구호와 긴급의료서비스 지원을 통해 재난피해자들의 고통을 경감시키는 인도주의정신 실천에 중요한 역할을 감당해왔다. 특히 국내재난현장에서의 축 적된 구호능력을 기반을 토대로 1997년부터 해외재난현장에 파견되어 해외구호의 경험을 쌓은 결과, 2011년 11월에 INSARAG 헤비 등급을 획득하는 성과를 이뤄냈다. 한편, 이러한 성과에도 불구하고 현재 우리나라 국제개발협력 예산에서 인도적 지원 비율이 1 2\% 수준에 그치고 있다. 선진 공여국들이 평균적으로 $6 \%$ 를 배분하고 적극적으로 인도적지원에 대한 전략과 프로그램을 발굴하고 있는 점을 감안 할 때, 우리나라 긴급구호대의 안정적 관리와 운영을 위한 재정지원비 율의 확대를 포함한 인도적지원의 예산 확대 그리고 동 수준을 달성할 수 있도록 구체적인 계획 과 이행과 평가의 중요성이 어느 때보다 더욱 중요한 정책 과제로 부각되어져야 할 것이다.

본 연구는 목적에서도 명시했듯이 조사대상국의 해외긴급구호 및 인도적 지원 관련 법·정책· 전략을 조사하여 시사점을 도출하였는데 이와 더불어 다음과 같이 후속연구방향을 제언하고자 한다.

첫째, 해외 인도적 지원과 긴급구호 분야에 있어 조사대상국의 범위를 좀 더 확대하는 보완연 구가 필요하다. 본 연구는 범위가 방대하면서도 대상의 층위가 상이함으로 인해 심도 있는 연구 를 수행하는데 다소 한계가 있었다. 이에 영미권과 유럽권 공여국들에 대한 추가조사가 이뤄진다 면 법제와 정책, 구호대 운영과 관련한 전반적인 추세를 포착할 수 있고 각 부문 별 유형화가 가 능하며 한국의 인도적 지원과 긴급구호에 있어 전략적으로 강화해야 할 부문을 보다 명확하게 인 식할 수 있을 것이다.

둘째, 센다이 프레임워크에서도 강조한 바 있는 지역 재난경감 및 대응협력체계 구축과 관련 동북아 재난경감 및 대응에 관한 협력 프레임워크 연구를 통해 한국이 주도적 역할을 할 수 있는 기반을 구축해야 할 필요가 있다.

셋째, 탐색구조대와 의료팀의 전문화 및 역량강화와 관련, 본 연구의 결과와 자료를 토대로 각 분야별로 심층적인 보완연구가 필요하다. 
넷째, 인도적 지원 거버넌스 차원의 평가 체계, 기관 차원, 전략차원, 사업차원의 평가와 모니 터링 체계가 구축을 위한 준비가 시급하다. 특히, 국제사회에서 통용되는 인도주의 원칙인 GHD 의 목표와 지표를 중심으로 인도적 지원의 효과성 제고 방안을 수립하여 전략차원과 사업차원의 평가와 보고 체계를 구축위한 조사 연구 작업이 필요할 것이다.

다섯째 호주와 스위스 공히 민간 전문가를 최대한 활용하고 민간단체들과의 협력을 강화하는 양태를 보이는 만큼 긴급구호 혹은 포괄적인 인도적 지원에 있어 민간인력 활용 및 민관 협력 프 레임워크에 대한 연구도 중장기적으로 유효할 것이다. 


\section{〈참고문헌〉}

관계부처 합동. 2010. “국제개발협력 선진화 방안". 서울: 국제개발협력위원회 . 2015. “국제개발협력 기본계획". 서울: 국제개발협력위원회

기획재정부 · 외교부. 2010. “국제개발협력 기본계획"

박명지. 2011. “한국 무상 ODA의 파트너십 제고 방안 연구: 정부 공공기관의 협력 체 계 구축을 중심으로”. 성남: 한국국제협력단

외교부. 2015. “인도적 지원 전략”. 서울: 외교부

외교부·한국국제협력단. 2015. "해외긴급구호 대책안"

이명근 · 홍문숙 · 김현정 · 문기홍 · 여국회 · 신보경. 2012. “인도적 지원정책 및 사업 연

구: 긴급구호 시스템을 중심으로”. 성남: 한국국제협력단

이영현 · 김주자· 권구순 · 장은하·이경신. 2013. "인도적 지원 분야 역량강화를 위한 중

장기 교육 및 훈련방안 연구”. 성남: 한국국제협력단

홍문숙 - 이태주 · 김형식 · 유성상 - 오수현. 2013. "타 해외 원조기관 정책 수립 및 사업

수행체계 연구”. 성남: 한국국제협력단

홍문숙 · 오수현 · 정성훈 - 신선연. 2014. "ODA와 아동: 국내외 원조기관 아동 정책 비교 연구”. 서울: 세이브더칠드런코리아

AHPPC. 2012. "National AusMAT Manuel Preparedness, deployment and postdeployment activities of Australian Medical Assistance Teams (AUSMAT) domestically and internationally"

AusAid. 2009. "Investing in a Safer Future: A Disaster Risk Reduction Policy for the Australian aid program". Canberra: AusAid

2010. "Integration in Practice: Integrating disaster risk reduction. climate change and environmental considerations in AusAID programs". Canberra: AusAid

. 2011a. "Humanitarian Action Policy". Canberra: AusAid

. 2011b. "An Effective Aid Program for Australia. Making a real difference- delivering real results". Canberra: AusAid 
. 2012a. "2011 Humanitarian Action Policy Implementation Plan".

Canberra: AusAid

. 2012b. "Progress Report for the DRR Policy". Canberra: AusAid 2012c. "Transparency Charter, Australian Aid Program". Canberra:

AusAid

Australian CivMil Centre(ACMC) and ACFID. 2012. "Same Space -Different

Mandates: A civil military guide to Australian stakeholders in international disaster and conflict response"

Galloway, C. 2013. "Municipal emergency response officers and local priorities in Australian emergency communication". Australian Journal of Emergency Management 28(3), pp.24-28

Government of Australia(GoA). 1998. "Australian Government Overseas Disaster Assistance Plan (AUSASSISTPLAN): Direction of the Director General Emergency Management Australia as Managing Agent for Disaster Assistance for the Australian Agency for International Development". Canberra: Government of Australia(GoA)

. 2009. "Strategic Partnership Agreement between the Department of Defence and the Australian Agency for International Development". Canberra: Government of Australia(GoA)

2010. "Australian Government Crisis Management Framework". Canberra: Government of Australia(GoA)

2015. "Australian Government Overseas Assistance Plan". Canberra: Government of Australia(GoA)

Government of Japan. 'Japan's ODA Charter(2003)'

. 2005. "Initiative for Disaster Risk Reduction through ODA". Tokyo: Government of Japan

. 2014. "Overview of Japan's ODA White Paper 2013: Development Cooperation as Investment in the Future". Tokyo: Government of Japan 2015. "Cabinet Decision on the Development Cooperation Charter". Tokyo: Government of Japan 
Government of Japan, MoFA. 2011. "Humanitarian Aid Policy of Japan". Tokyo: Ministry of Foriegn Affiars of Japan(MoFA) 2011. "Outline of Humanitarian Aid Policy". Tokyo: Government of Japan. MoFA

. 2014. "Evaluation of Humanitarian Assistance in Case of Emergency".

Tokyo: Government of Japan. MoFA

. 2015. "Priority Policy for Development Cooperation FY 2015". Tokyo: Government of Japan. MoFA

GHD. 2003. "The Principles and Good Practice of Humanitarian Donorship, Declaration made in Stockholm"

NCCTRC. 2011. "AusMAT Handbook 2011". Darwin: NCCTRC

OECD. 2011. "OECD Development Co-operation Peer Review Australia (2013)

The Development Assistance Committee: Enabling effective development". Paris: OECD

Swiss Confederation. 2012. "Message on International Cooperation 2013-2016:

Key point in brief". Bern: Swiss Confederation

Swiss Agency for Development and Cooperation. 2011. "SDC Humanitarian Aid:

Emergency Relief. Evaluation". Bern: Swiss Agency for Development and Cooperation(SDC)

. 2012a. "SDC Multilateral Humanitarian Aid Concept". Bern: Swiss Agency for Development and Cooperation(SDC)

. 2012b. SDC Portrait: The SDC- reliable, sustainable, innovative.

. 2013. "Swiss Humanitarian Aid: Saving Lives, Alleviating Suffering".

Bern: Swiss Agency for Development and Cooperation(SDC)

UNOCHA. 2015. "INSARAG Guidelines Volume II: Preparedness and Response

Manual C: INSARAG External Classification and Reclassification". New York: UNOCHA

Vonderen, J., \& Bligh, A. 2009. "Emergency Aid: The largest overseas emergency response ever mounted by Queensland has begun. Stateline QLD (ABC1 Brisbane)"

WHO. 2013. "Classification and Minimum Standards for Foreign Medical Team in Sudden Onset Disasters". Geneva: WHO 